\title{
Étienne Jodelle, Théâtre complet. Tome I: L'Eugène
}

\section{Michele Mastroianni}

\section{(2) OpenEdition}

\section{Journals}

\section{Edizione digitale}

URL: http://journals.openedition.org/studifrancesi/6244

DOI: $10.4000 /$ studifrancesi.6244

ISSN: 2421-5856

\section{Editore}

Rosenberg \& Sellier

\section{Edizione cartacea}

Data di pubblicazione: 1 novembre 2010

Paginazione: 542

ISSN: 0039-2944

\section{Notizia bibliografica digitale}

Michele Mastroianni, «Étienne Jodelle, Théâtre complet. Tome I: L'Eugène», Studi Francesi [Online], 162

(LIV | III) | 2010, online dal 30 novembre 2015, consultato il 08 janvier 2021. URL: http://

journals.openedition.org/studifrancesi/6244 ; DOI: https://doi.org/10.4000/studifrancesi.6244

Questo documento è stato generato automaticamente il 8 janvier 2021.

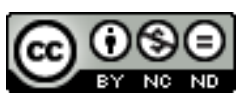

Studi Francesi è distribuita con Licenza Creative Commons Attribuzione - Non commerciale - Non opere derivate 4.0 Internazionale. 


\title{
Étienne Jodelle, Théâtre complet. Tome I: L'Eugène
}

\author{
Michele Mastroianni
}

\section{NOTIZIA}

ÉTIENNE JODELLE, Théâtre complet. Tome I: L'Eugène, édition de Luigia zILLI, Paris, Éditions Classiques Garnier, 2009 («textes de la Renaissance», 154), pp. 159.

1 Dopo l'edizione della Didon se sacrifiant (Paris, Champion, 2002, «textes de la Renaissance, 62»), il Théatre complet di Jodelle pubblicato sotto la direzione di Ch. de Buzon e J.-Cl. Ternaux si arricchisce dell'edizione critica de L'Eugène, la prima commedia francese composta ad imitazione dei classici nel 1552 (ma pubblicata postuma nel 1574, all'interno de Les Euvres et Meslanges Poëtiques d'Estienne Jodelle, su cui si fonda la presente edizione critica). Preceduta da traduzioni mot à mot e libere di Terenzio e dalla traduzione di una commedia degli Intronati di Siena, che aprirà l'imitazione del genere anche alla commedia erudita italiana, L'Eugène offre un esempio di commedia che, pur riprendendo tematiche della farsa tradizionale (per esempio, il cocuage, la satira dei costumi del clero, il paragone dello stato militare e di quello ecclesiastico, ecc.) e ambientando la trama in un contesto parigino, costruisce la storia come una perfetta comédie à l'antique. Luigia Zilli, nella sua introduzione, illustra con chiarezza lo strutturarsi di questa forma classicista e nello stesso tempo i legami con la tradizione francese e la dimensione realistica della narrazione; in particolare, nelle annotazioni mette in evidenza i rapporti con la letteratura satirica del Quattro e Cinquecento. Un paragrafo interessante è consacrato all'uso dell'ottosillabo e alla creazione di un linguaggio comico originale. Esauriente la bibliografia e accurato il glossario. 